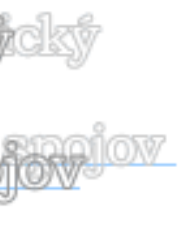

\title{
VPLYV INDUSTRY 4.0 NA PODMIENKACH POSKYTOVATELA UNIVERZÁLNEJ POŠTOVEJ SLUŽBY
}

\section{Lucia Madleňáková ${ }^{1}$}

\begin{abstract}
The paper is devoted to the issue of the impact of the fourth industrial revolution on the working area of employees working in the postal and logistics sector. The main objective of the paper is the analysis and subsequent quantification of the impact of the fourth industrial revolution, respectively automation and digitization for the work area of employees. The results are modeled situations and examined dependencies between aspects that are expected to have an impact on employment.
\end{abstract}

Keywords: Industry 4.0, Logistics 4.0, last mile logistics, employees, regression analysis

\section{Úvod}

Dlhodobo platí, že odvetvie poštových a logistických služieb je rýchlo sa rozvíjajúcim a rastúcim odvetvím. Tento fakt nevyplýva len z rastúcich objemov spracovávaných zásielok a požiadaviek $\mathrm{v}$ oblasti výrobnej a distribučnej logistiky. Je vyvolaný predovšetkým inováciami voblasti automatizácie, robotizácie a digitalizácie, ktoré zasahujú celý dodávatel'ský ret'azec. Dopady Industry 4.0 či už tie pozitívne (automatizácia procesov, zvyšovanie efektívnosti, znižovanie chybovosti, ...), ale aj tie spoločensky negatívne (znižovanie počtu pracovných miest v určitých segmentoch) sa nevyhnú ani poskytovatel'om univerzálnej poštovej služby a to aj napriek tomu, že správanie mnohých inkumbentov je stále konzervatívne. Inovácie súvisiace s nástupom Industry 4.0 sú typické skôr pre svetových integrátorov (DHL, UPS, FEDEX, TNT) a pre nadnárodných poštových operátorov (DPD, GLS, Geis, Hermes, ....). Súvisia však aj s vyspelost’ou krajiny a ochotou vlád vytvárat' podmienky pre rast inovačného potenciálu krajiny.

\section{Analýza súčasného stavu}

Podla rebríčka GII (Global Innovation Index) je Slovensko na 39. mieste zo 131 hodnotených krajín. Zaostáva aj za krajinami V4. Najviac zaostalo v kategórii „Sofistikovanost' trhu“, kde ho GII zaradil až na 82. miesto. Ocitlo sa zároveň aj medzi jedenástkou ekonomík sveta, ktoré v oblasti inovácií dosahujú ešte nižšie výsledky, ako by sa dalo očakávat' $\mathrm{v}$ súvislosti $\mathrm{s}$ úrovňou ich rozvoja. Najviac z krajín V4 sa darí Českej republike. V rebríčku je 24. a podarilo sa jej predbehnút' Estónsko. Celkovo sa inovácie v súčasnosti sústred'ujú na úrovni vedeckých a technologických klastrov vo vybraných ekonomikách s vysokými príjmami a hlavne v Č́ne, a posúvajú sa do krajín ako je Vietnam, India a Filipíny. Z Európskych krajín je na vrchole rebríčka Švajčiarsko a Švédsko, z ostatných krajín dominujú Spojené štáty americké.[18]

\footnotetext{
${ }^{1}$ doc. Ing. Lucia Madleňáková, PhD., Katedra spojov, FPEDAS, Žilinská univerzita v Žiline, e-mail: lucia.madlenakova@fpedas.uniza.sk
} 
V marci 2019 Európska rada vo svojej výzve uviedla, že Európa potrebuje zvýšit' svoje inovačné schopnosti, ak chce konkurovat' na svetových trhoch, udržat' si európsky spôsob života. Preto stanovila ambicióznejšie ciele práve pre oblast' výskumu a inovácií. Výkonnost' inovačných systémov meraná prostredníctvom EIS (European innovation scoreboard) je zameraná na hodnotenie 27 ukazovatel’ov výkonnosti. Na základe počtu bodov sa krajiny EÚ delia na štyri výkonnostné skupiny: inovační lídri, silní inovátori, mierni novátori a skromní inovátori. Slovensko sa zarad'uje medzi miernych inovátorov. [10,15,23] Inovačná výkonnost' EÚ sa síce už štyri roky po sebe zlepšuje, a po prvýkrát v histórii vykázala Európa v oblasti inovácií lepšie výsledky než Spojené štáty, no voči Japonsku a Južnej Kórei nad’alej zaostáva a rýchlo ju dobieha aj Cína.

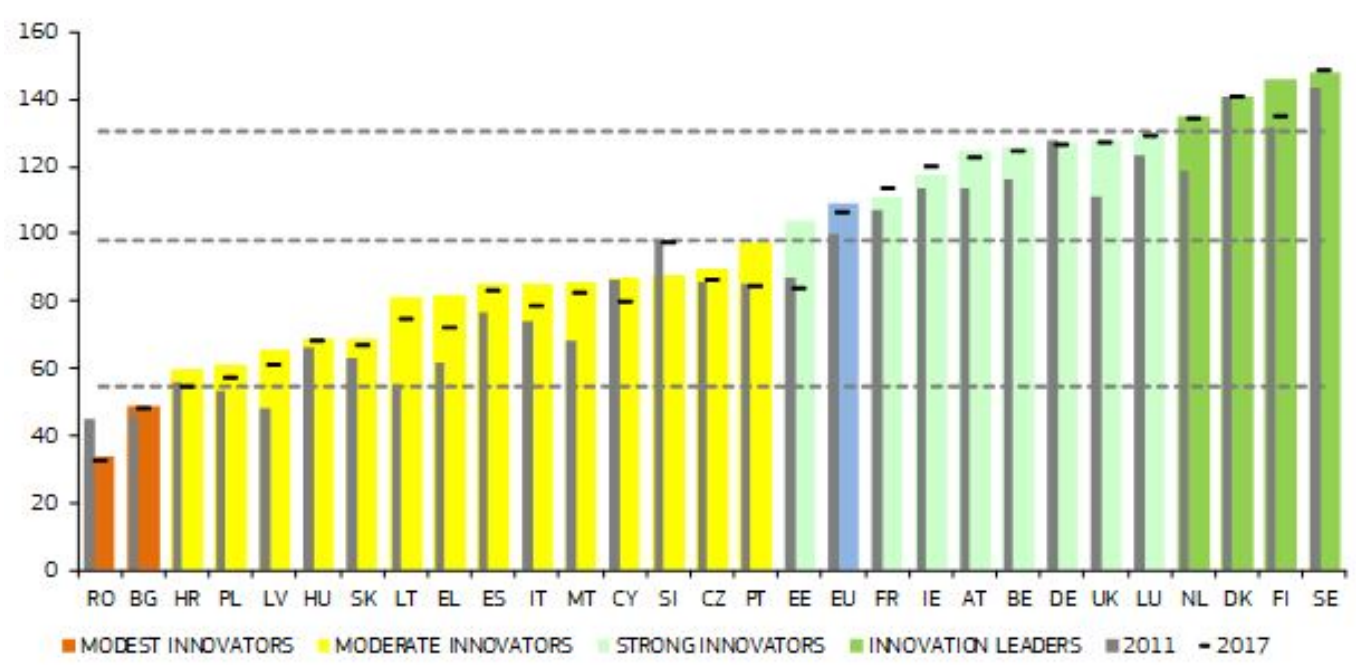

Obrázok 1 hodnotenie inovačnej výkonnosti podla EIS na rok 2019 [23]

Nakol'ko sa inovačná politika stáva čoraz väčšou prioritou členských krajín únie, na podporu inovácií sa prijali a implementovali rôzne podporné programy. Štátna podpora inovácií $\mathrm{v}$ rozvinutých ekonomikách je považovaná za akúsi záruku kvality projektov pre vstup súkromných investorov, a to najmä v technologických oblastiach, ktoré sú náročné na kapitál. Krajiny ako Rakúsko, Estónsko, Portugalsko či Pol'sko výrazne podporujú inovácie nielen finančne, ale aj legislatívnym prostredím napr. daňovými zvýhodneniam, fungujúcim e-governmentom či tzv. startupovými vízami, ktoré umožňujú inovátorom z krajín mimo EÚ rozvíjat' svoje nápady aj v krajinách EÚ. [10, 14]

Slovensko patrí ku krajinám s nízkym až stredným inovačným potenciálom. Avšak v oblasti implementácie robotických riešení, či iných nástrojov Industry 4.0 patrí najme v sektore automobilového priemyslu k špičke (tretie miesto v Európe). Záujem o robotizáciu a automatizáciu sa zvyšuje aj v iných odvetviach. Dôvodov je hned' niekol'ko: rastúce mzdy, vyššia spol'ahlivost' strojov, nutnost' vyrábat' rýchlo a kvalitne, ale aj nedostatok pracovnej sily. [17] K dôvodom nízkeho inovačného potenciálu v SR patrí nedostatok kvalitných výskumných inštitúcií, ktoré by boli zapojené do európskeho priestoru. Ide prevažne o chýbajúce výskumné centrá pridružené k centrám výrobným. Výzvou pre najbližšie obdobie je efektívna spolupráca človek-robot, vývoj modulov do robotického operačného systému a vývoj univerzálneho uchopovacieho zariadenia, nasadzovanie dronov aj vo vnútornom prostredí a rozvíjanie autonómnych robotov, pričom treba dbat' na zlepšovanie ich zmyslov a inteligencie. Z netechnickej stránky je potrebné zaoberat' sa legislatívou v robotike, ktorá významne ovplyvní výskum i prax.[17]

\section{Industry 4.0 v sektore poštových a logistických služieb}

Oblast' poštových a logistických služieb je dnes vystavená mnohým výzvam Industry 4.0. V prvom rade je to očakávaná zmena princípov riadenia tokov výroby a následne 
distribúcie, rovnako tak riadenia tokov v dodávatel'skom ret'azci pre e-commerce. Simulácie procesov a optimalizácia logistických procesov je v súčasnosti považovaná za samozrejmost'. $\mathrm{K}$ tomu je potrebné počítat' $\mathrm{s}$ technologickými zmenami $\mathrm{v}$ obslužných zariadeniach, spracovatel'ských a distribučných centrách, s jednoznačnou identifikáciou zásielok a okamžitou dostupnost'ou (l'ubovol'nom čase) informácií o potrebách technologického systému, o stave zásielok a pod. V tejto súvislosti môžeme zhrnút' aj výzvy pre oblast' distribúcie zásielok a to je predovšetkým spracovanie vel'kého množstva dát súvisiacich $\mathrm{s}$ rastúcim objemom online obchodovania a tiež zabezpečenie efektívnej distribúcie. Napr. René Stranz (Gebrüder Weiss Slovensko) vyjadril presvedčenie, že sa musí postupovat' a zaobchádzat' vel'mi opatrne predovšetkým so zákazníckymi dátami, ktoré majú obrovskú hodnotu. Ide najmä o zabezpečenie cloudových úložisk dát, ktoré by mali byt' realizované tak, aby mal zákazník dáta kedykol’vek k dispozícii, na druhej strane musia byt' dostatočne chránené. Zákazníci najmä pri službách distribúcie pre online nakupovanie vyžadujú presné informácie o stave spracovania zásielky ako aj dostupnost' služieb s pridanou hodnotou, ktoré sú na informačné toky naviazané. Ďalšou významnou požiadavkou je transparentný dodávatel'ský ret'azec a optimalizácia trás vo väzbe na kratšiu lehotu dodania a zodpovedné environmentálne správanie predovšetkým vo fáze poslednej míle. V podobnom duchu je možné uviest' aj vyjadrenia Martina Morhača (SOVA Digital) ako aj účastníkov mnohých odborných diskusných fór a workshopov, ktorí okrem iného uvádzajú, ako významný aspekt tzv. Logistiky 4.0 práve l'udský faktor. [12, 16, 21]

V nadväznosti na uvedené je možné uviest' príklady uplatňovania nástrojov Industry 4.0 pre jednotlivé fázy premiestňovacieho procesu:

- Nástroje pre procesy vyberania: IoT, Drony, Cloud computing.

- Nástroje pre procesy distribúcie: NFC, Cloud computing, IoT, Drony, Autonómne roboty, Rozšírená realita, Automatizované triediace systémy, Vnútro-skladové drony.

Je možné tiež predpokladat', že mnohé pracovné pozície, ktoré v súčasnosti zastáva v distribúcií zásielok a tovaru človek budú postupne nahrádzané nástrojmi automatizácie a robotizácie. Svedčí o tom čoraz väčší nástup takýchto nástrojov aj do prostredia samoobslužných skladov a pod.

\section{Ciele a metodika}

Príspevok je zameraný na modelovanie a skúmanie závislosti medzi vybranými charakteristikami počet zamestnancov či objemy spracovávaných zásielok čo je a $\mathrm{v}$ budúcnosti môže byt' omnoho významnejšie ovplyvnené digitalizáciou a automatizáciou procesov. Skúmanie je realizované na v podmienkach poskytovatela univerzálnej poštovej služby. Pre kvantifikáciu výstupov bola použitá korelačná analýza s ciel'om skúmat' závislost' medzi dvomi premennými. Výpočet bol realizovaný na základe lineárneho regresného modelu $y=b_{0}+b_{1} * x$

kde: $\quad b_{0}$ - lokujúca konštanta vyjadruje očakávanú úroveň závislé premennej pri nulovej hodnote nezávisle premennej

b1 - regresný koeficient vyjadruje o kol'ko merných jednotiek sa zmení závislé premenná pri zmene nezávisle premennej o jednu mernú jednotku

ak

b1 $>0$ ide o pozitívnu závislost'

$b_{1}<0$ ide o negatívnu závislost' $[6,7,20]$

Následne bol vypočítaný koeficient determinácie $r_{x, y}^{2}, \in<0,1>$ ktorý predstavuje podiel variability premennej y vysvetlenej lineárnym regresným modelom a testom významnosti korelačných koeficientov sa testovala jeho štatistická významnost'. [6,7,20] Štatistické údaje použité v sekundárnom a primárnom výskume pochádzajú zo zdrojov Eurostatu, OECD ako aj MDV SR a SP, a.s. 


\section{Výsledky a diskusia}

Implementácia nových technológií a digitalizácie má významný vplyv na spoločnost'. Nejde len o zmeny v spôsobe výroby, obchodu a distribúcie. Menia sa modely zamestnanosti. To je dôvodom záujmu o vývoj zamestnanosti nielen v oblasti IKT odborníkov (ovplyvňujú konkurenčnú výhodu krajiny), ale aj vývoj zamestnanosti v segmente populácie s nízkym stupňom vzdelania, ktorá sa javí ako najviac ohrozená nástupom automatizácie a robotizácie.

Štatistické údaje Eurostatu naznačujú, že podiel IKT špecialistov na celkovej zamestnanosti nie je v žiadnej z krajín uspokojivý. Rastúce tendencie sa zastavili v krajinách V4 v roku 2009. Následne v roku 2010 prudko klesli a ich vývoj sa až do súčasnosti drží pod priemerom EÚ (3,7\% z celkovej zamestnanosti v roku 2017). Ohrozenou skupinou vo všetkých oblastiach zamestnanosti sú ženy. Ich podiel v segmente IKT je nízky. Najmä na Slovensku podiel žien v IKT sektore tvorí len cca 9\%. [19, 22]

Ďalšie skúmanie je možné opierat' aj o štúdie významných autorov ktoré poukazujú na dopady Priemyslu 4.0 na trh práce.[1,2,5]

Skúmanie závislosti počtu zamestnancov poskytovatel'a univerzálnej služby vo väzbe na vybrané aspekty digitalizácie

Zmeny v požiadavkách na poštové služby sú spojené predovšetkým s využívaním substitučných služieb a nástrojov elektronickej komunikácie. V tejto súvislosti sa predpokladá, že vývoj počtu pripojení na internet má vplyv na dostupnost' a využívanost' online nakupovania, ale aj komunikácie v segmentoch $\mathrm{C} 2 \mathrm{C}, \mathrm{B} 2 \mathrm{C}, \mathrm{G} 2 \mathrm{C}$ čo sa následne prejaví v zmenách objemov niektorých poštových služieb. $Z$ toho dôvodu je predmetom skúmania závislosti vývoj počtu pripojení na internet a jeho vplyv na objemy balíkových a listových zásielok, ale aj závislost' medzi zmenou množstva zásielok a počtom zamestnancov poskytovatel'a univerzálnej poštovej služby.

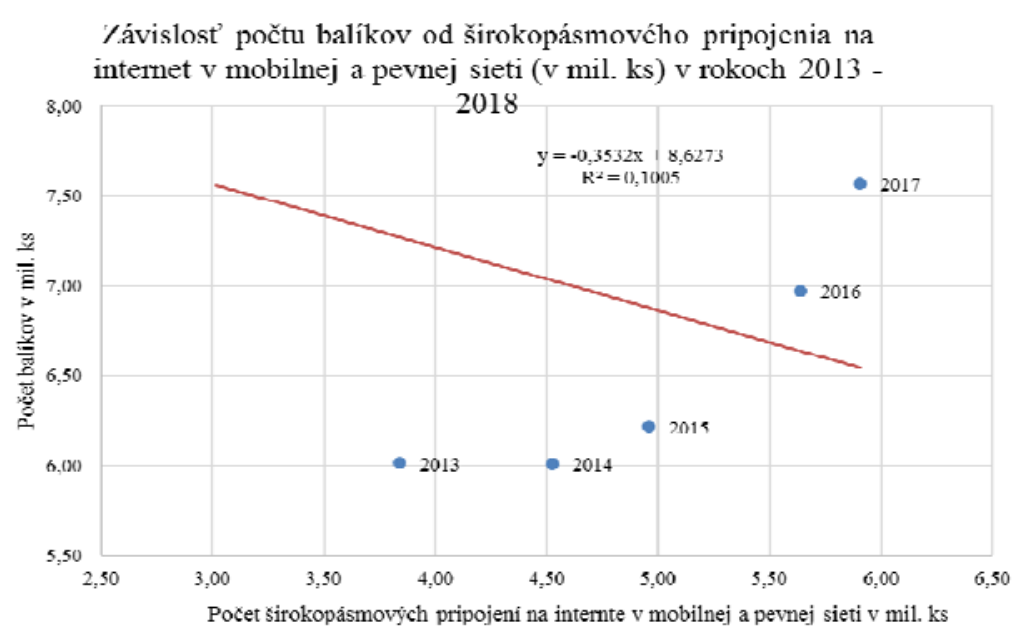

Obrázok 2 Závislost’ počtu balíkov od širokopásmového pripojenia na internet (Zdroj: autor)

Obrázok 2 znázorňuje modelovanie závislosti počtu balíkov v mil. ks od počtu širokopásmových pripojení na internet $\mathrm{v}$ mobilnej aj pevnej sieti v SR - je vysvetlených $10,05 \%$ variability $\mathrm{v}$ počte balíkov prostredníctvom lineárneho regresného modelu. Táto závislost' je malá $\left(\mathrm{r}^{2}=0,1\right)$ a je štatisticky nevýznamná. Možno ju interpretovat' nasledovne: predpokladaný pokles počtu širokopásmových pripojení na internet v mobilnej aj pevnej sieti v SR o 1 milión je sprevádzaný nárastom počtu balíkov v priemere približne o 0,35 . Pri rovnakom vývoji počtu pripojení na internet $\mathrm{v}$ nasledujúcich rokoch je potom predpokladaný každoročný nárast balíkov o 1 milión (podl’a predpokladu skúmanej závislosti). 


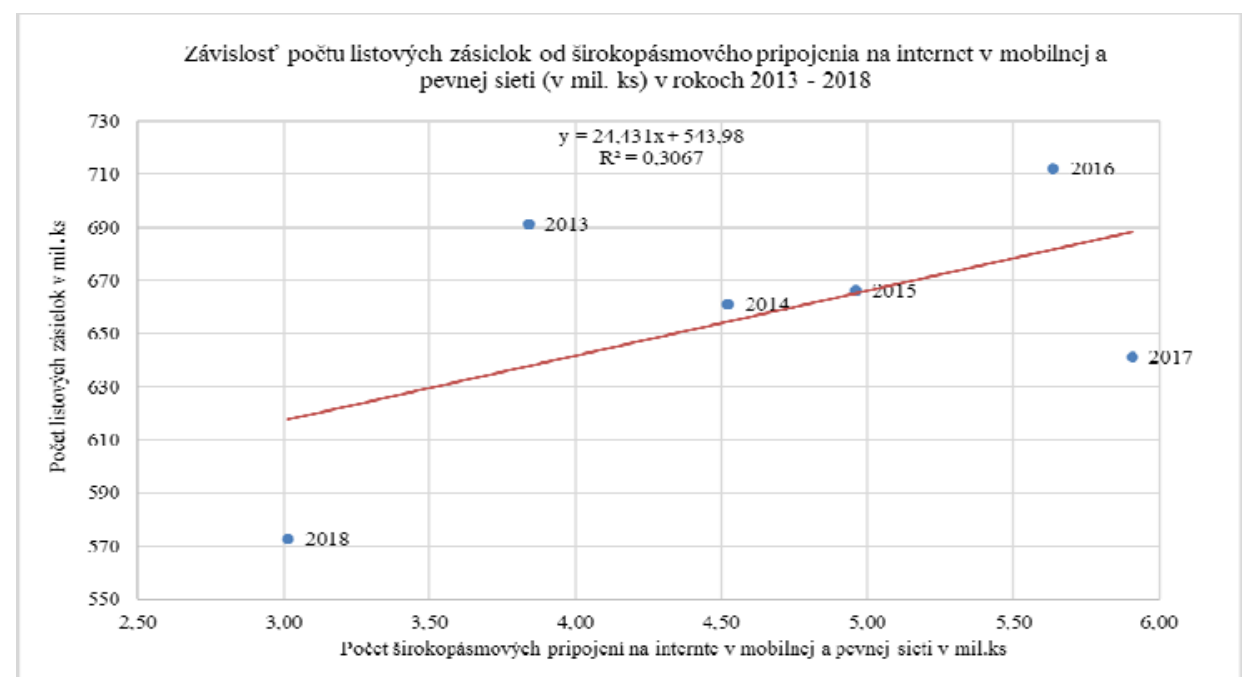

Obrázok 3 Závislost' počtu listových zásielok od širokopásmového pripojenia na internet (Zdroj: autor)

Obrázok 3 znázorňuje lineárnym regresným modelom závislosti počtu listových zásielok v mil. ks od počtu širokopásmových pripojení na internet v SR čím je vysvetlených $30,67 \%$ variability $\mathrm{v}$ počte listových zásielok. Táto závislost' je stredná $\left(\mathrm{r}^{2}=0,31\right)$ a je štatisticky nevýznamná. Možno ju interpretovat' nasledovne: pokles počtu širokopásmových pripojení na internet v SR o 1 milión je sprevádzaný poklesom počtu listových zásielok $\mathrm{v}$ priemere približne o 24,43 mil. ks. Pri rovnakom vývoji pripojení na internet v nasledujúcich rokoch je predpokladaný každoročný pokles listových zásielok o 73,78 mil. ks.

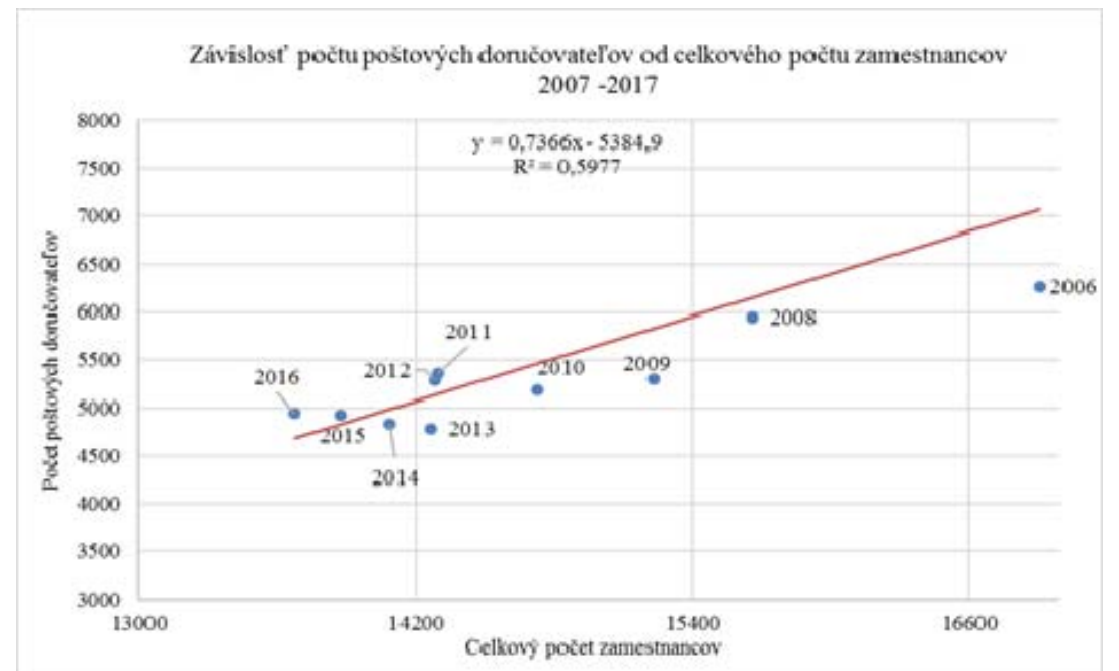

Obrázok 4 Závislost' počtu poštových doručovatel’ov od celkového počtu zamestnancov (Zdroj: autor)

Obrázok 4 znázorňuje modelovanie závislosti počtu poštových doručovatel’ov od celkového počtu zamestnancov čo je vysvetlených $59,77 \%$ variability v počte poštových doručovatel'ov prostredníctvom lineárneho regresného modelu. Táto závislost' je vel'ká $\left(\mathrm{r}^{2}=\right.$ 0,6 ) a štatisticky nevýznamná. Možno ju interpretovat' nasledovne: predpokladom pri poklese celkového počtu zamestnancov spolu o 1 tisíc je sprevádzaný poklesom počtu poštových doručovatel'ov v priemere približne o 7,37. Počet doručovatel'ov v skúmaných rokoch rastie aj ked' celkový počet zamestnancov klesá. Poštoví doručovatelia nie sú priamo v ohrození napriek tomu, že pokles pripojení je sprevádzaním klesaním listových zásielok, ktoré tvoria najväčšiu čast' zo spracovávaných zásielok, rastie však objem spracovávaných balíkových zásielok. 
Použitím lineárneho regresného modelu sú znázornené na obrázku 5 závislosti počtu zamestnaných žien od celkového počtu zamestnancov je vysvetlených 95,75\% variability v počte zamestnaných žien. Táto závislost' je takmer dokonalá $\left(\mathrm{r}^{2}=0,95\right)$ a je štatisticky významná. Možno interpretovat', že pokles celkového počtu zamestnancov o 1 tisíc je sprevádzaný poklesom počtu zamestnaných žien v priemere približne o 7,23.

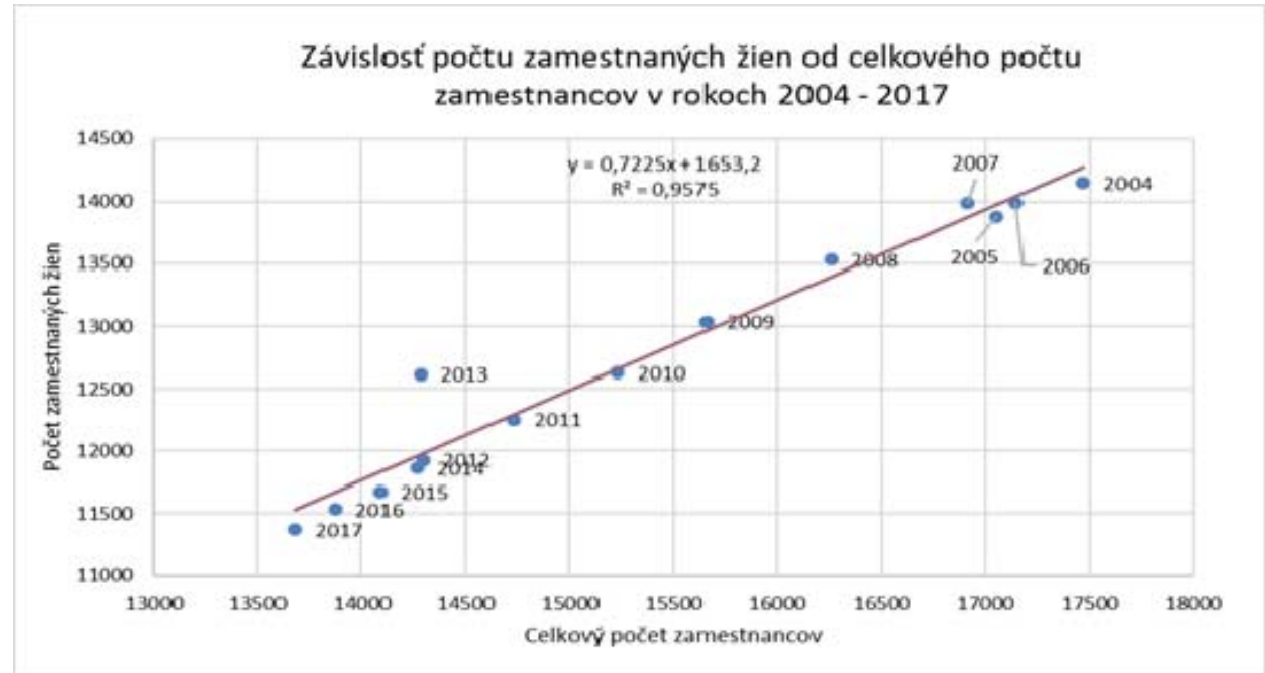

Obrázok 5 Závislost' počtu zamestnaných žien od celkového počtu zamestnancov (Zdroj: autor)

Pomer zamestnaných žien u národného operátora za skúmané roky sa pohybuje na úrovni cca $83 \%$. Digitalizácia predstavuje vel'ké riziko pre ženy zamestnané v tomto odvetví pretože pokles celkového počtu zamestnancov je sprevádzaný poklesom zamestnaných žien.

\section{Skúmanie závislosti vo väzbe na automatizáciu a časovú náročnost' práce zamestnancov vo vybranom spracovatel'skom stredisku poskytovatel'a univerzálnej služby}

Vo väzbe na Industry 4.0 v poštovom a logistickom odvetví rastú aj požiadavky aj na tvorbu a úpravu pracovného prostredia. Požiadavky sa týkajú predovšetkým zlepšovania pracovných postupov a implementovania moderných pracovných prostriedkov a nástrojov. Tieto aspekty majú prispiet' $\mathrm{k}$ zlepšeniu pracovného výkonu, zníženiu časovej náročnosti práce najmä pri spracovávaní časovo náročných zásielok (zásielky 1. triedy, expres zásielky), redukcii chybovosti a k zníženiu neprimeranej fyzickej pracovnej zát’aže.

Spracovanie zásielok na spracovatel'ských strediskách poskytovatel'a univerzálnej služby je realizované podl'a stanovených technologických postupov. V závislosti od druhu poštovej zásielky a požiadaviek vyplývajúcich z doplnkových služieb sú zásielky pridelené na jednotlivé pracoviská, ktoré umožňujú využívanie mechanizácie a automatizácie, resp. pri vybraných druhoch zásielok je použivané výhradne ručné (manuálne) triedenie.

Pri skúmaní technologickej zát'aže (tabul'ka 1) je potrebné pracovat's údajmi o počte zamestnancov obsluhujúcich triediace linky. Triediace linky pracujú s rovnakou rýchlost'ou, pričom každá listová zásielka vhodná na automatizované spracovanie, je spracovávaná na oboch triediacich linkách. Na skúmanom pracovisku obsluhu CRS linky vykonávajú 3 zamestnanci a obsluhu FSM linky vykonávajú 4 až 5 zamestnanci. Balíkové zásielky sa delia na vhodné a nevhodné na automatizované spracovanie, kde je potrebné brat' do úvahy hmotnost', rozmery zásielky a pohlavie zamestnanca (rozdielne obmedzenia pri práci z bremenami pre ženy a mužov). Pri balíkoch vhodných na strojné spracovanie sú využívané plne automatizované triediace linky. Obsluhu balíkovej triediacej linky vykonáva 4 až 5 zamestnancov pri výstupoch stroja, a 1 až 3 zamestnanci na vstupných pracoviskách. Pričom výkon jedného vstupného pracoviska je cca 500 až 1200 zásielok za hodinu. Triediarne poštových zásielok sú klasifikované stupňom náročnosti práce 2 . 
Tabul'ka 1 Základné charakteristiky spracovávania listových a balíkových zásielok

\begin{tabular}{|c|c|c|c|c|c|c|c|}
\hline & \multicolumn{4}{|c|}{ Listové zásielky } & \multicolumn{3}{|c|}{ Balíkové zásielky } \\
\hline & \multicolumn{2}{|c|}{$\begin{array}{c}\text { Nevhodné na strojné } \\
\text { spracovanie }\end{array}$} & \multicolumn{2}{|c|}{ Vhodné na strojné spracovanie } & \multirow{2}{*}{$\begin{array}{c}\text { Nevhodné na } \\
\text { strojné } \\
\text { spracovanie }\end{array}$} & \multirow{2}{*}{\multicolumn{2}{|c|}{$\begin{array}{c}\begin{array}{c}\text { Vhodné na } \\
\text { strojné } \\
\text { spracovanie }\end{array} \\
\text { Balíkový } \\
\text { triedič BTL }\end{array}$}} \\
\hline & $\begin{array}{c}\text { Malé } \\
\text { rozmery }\end{array}$ & $\begin{array}{c}\text { Vel'ké } \\
\text { rozmery }\end{array}$ & ATL CRS & ATL FSM & & & \\
\hline $\begin{array}{l}\text { Rýchlost' } \\
\text { spracovania } \\
\text { zásielok v ks/h }\end{array}$ & $800-1500$ & $400-500$ & $25000-30000$ & $25000-30000$ & $200-300$ & 500 & 1200 \\
\hline \multirow{2}{*}{$\begin{array}{l}\text { Počet } \\
\text { zamestnancov }\end{array}$} & \multirow{2}{*}{1} & \multirow{2}{*}{1} & \multirow{2}{*}{3} & \multirow{2}{*}{$4-5$} & \multirow{2}{*}{1} & Vstup & Výstup \\
\hline & & & & & & $1-3$ & $4-5$ \\
\hline $\begin{array}{l}\text { Priemerný } \\
\text { počet zásielok } \\
\text { /1zamestnnaca }\end{array}$ & 1150 & 450 & \multicolumn{2}{|c|}{7638,89} & 250 & 425 & 212,5 \\
\hline
\end{tabular}

Zdroj: autor

Pre obmedzenost' rozsahu príspevku sú uvádzané len vybrané skúmané závislosti pre kategóriu listové zásielky. Vstupné údaje použité pre modelovanie vychádzali z technologickej zát’aže (počet spracovávaných zásielok v ks za jednotlivé roky) a následne z údajov určujúcich čas spracovania zásielok (ročný objem) jedným zamestnancom priemernou rýchlost’ou v hodinách.

Tabul'ka 2 Technologická zát'až spracovaných listov v HHS ZA v mil. ks 2011 - 2018

\begin{tabular}{|l|c|c|c|c|c|c|c|c|}
\hline & $\mathbf{2 0 1 1}$ & $\mathbf{2 0 1 2}$ & $\mathbf{2 0 1 3}$ & $\mathbf{2 0 1 4}$ & $\mathbf{2 0 1 5}$ & $\mathbf{2 0 1 6}$ & $\mathbf{2 0 1 7}$ & $\mathbf{2 0 1 8}$ \\
\hline Vhodné & 59861841 & 55496172 & 50651437 & 49247156 & 46366080 & 39663874 & 44981447 & 43914047 \\
\hline Nevhodné & 31061876 & 29279578 & 26878048 & 24425170 & 23834867 & 26908607 & 23516194 & 19949881 \\
\hline Vel'ké kusy & 18759765 & 15258895 & 15151433 & 14850907 & 14622801 & 20621293 & 22154403 & 20810249 \\
\hline
\end{tabular}

Tabul'ka 3 Čas spracovania zásielok jedným zamestnancom priemernou rýchlost’ou v hod.

\begin{tabular}{|c|c|c|c|c|c|c|c|c|}
\hline & 2011 & 2012 & 2013 & 2014 & 2015 & 2016 & 2017 & 2018 \\
\hline Vhodné & 7836,46 & 7264,95 & 6630,73 & 6446,90 & 6069,74 & 5192,36 & 5888,48 & 5748,75 \\
\hline Nevhodné & 27010,33 & 25460,50 & 23372,22 & 21239,28 & 20725,97 & 23398,79 & 20448,86 & 17347,72 \\
\hline Vel'ké kusy & 41688,37 & 33908,66 & 33669,85 & 33002,02 & 32495,11 & 45825,10 & 49232,01 & 46245,00 \\
\hline
\end{tabular}

1. Závislost' časového zat'aženia jedného zamestnanca od technologickej zát'aže spracovaných listov (vhodných na automatizované spracovanie) za roky 2007 - 2018

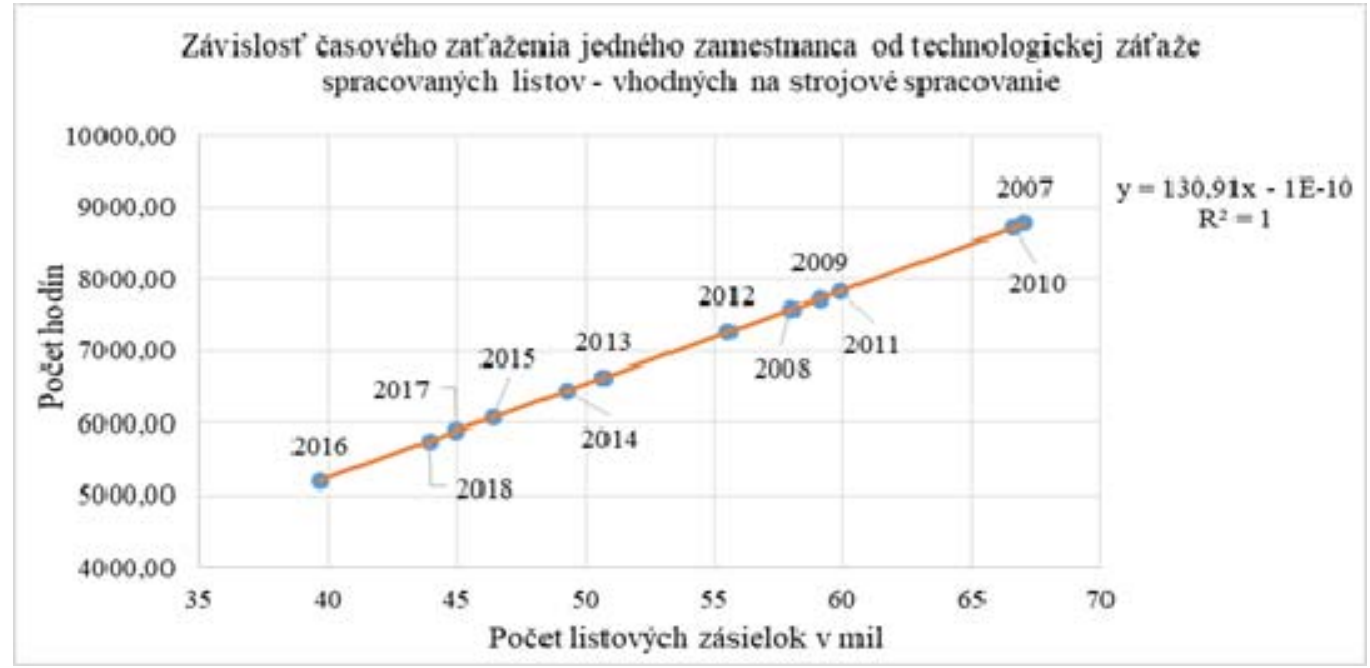

Obrázok 6 Závislost’ časového zat’aženia jedného zamestnanca od technologickej zát’aže spracovaných listov vhodných na strojové spracovanie 2007 - 2018 (Zdroj: autor) 
Obrázok 6 znázorňuje modelovanie lineárnym regresným modelom a to prepočítaný počet hodín na jedného zamestnanca od počtu listových zásielok vhodných na strojové spracovanie kde je vysvetlených $100 \%$ variability v počte hodín. Táto závislost' je takmer dokonalá $(\mathrm{r} 2=1)$ a je štatisticky významná. Nárast poklesu listových zásielok o 1 milión je sprevádzaný poklesom počtu hodín $\mathrm{v}$ priemere približne o 130,91. Z dôvodu triedenia listových zásielok automatizovanými triediacimi linkami časová náročnost’ na jedného zamestnanca je vel'mi nízka.

2. Modelovanie situácia „kol'ko hodín by jeden zamestnanec potreboval na vytriedenie listových zásielok v prípade ak by tieto zásielky triedil ručne" vychádza z prepočítanej technologickej zát'aže a časovej náročnosti (tabul'ka 4).

Tabul'ka 4 Počet hodín spracovania celého objemu listových zásielok (LZ) vhodných na strojné spracovanie vytriedených ručne jedným zamestnancom

\begin{tabular}{|l|r|r|r|r|r|r|r|r|}
\hline & $\mathbf{2 0 1 1}$ & $\mathbf{2 0 1 2}$ & $\mathbf{2 0 1 3}$ & $\mathbf{2 0 1 4}$ & $\mathbf{2 0 1 5}$ & $\mathbf{2 0 1 6}$ & $\mathbf{2 0 1 7}$ & $\mathbf{2 0 1 8}$ \\
\hline $\begin{array}{l}\text { Vhodné LZ triedené } \\
\text { ako malé zásielky }\end{array}$ & 52053,77 & 48257,54 & 44044,73 & 42823,61 & 40318,33 & 34490,33 & 39114,30 & 38186,13 \\
\hline $\begin{array}{l}\text { Vhodné LZ triedené } \\
\text { ako vel'ké kusy }\end{array}$ & 133026,31 & 123324,83 & 112558,75 & 109438,12 & 103035,73 & 88141,94 & 99958,77 & 97586,77 \\
\hline
\end{tabular}

(Zdroj: autor)

Ak by listové zásielky, ktoré sú v súčasnosti spracovavané automatizovane boli spracovávané ručne obdobnou rýchlost'ou ako malé listové zásielky nevhodné na automatizované spracovanie, efektívnost' jedného zamestnanca by klesla o 84,95 \%. V prípade, že by listové zásielky vhodné na strojné spracovanie boli triedené rýchlost'ou, ako vel'ké listové zásielky nevhodné na automatizované spracovanie efektívnost' jedného zamestnanca by klesla o $94,11 \%$.

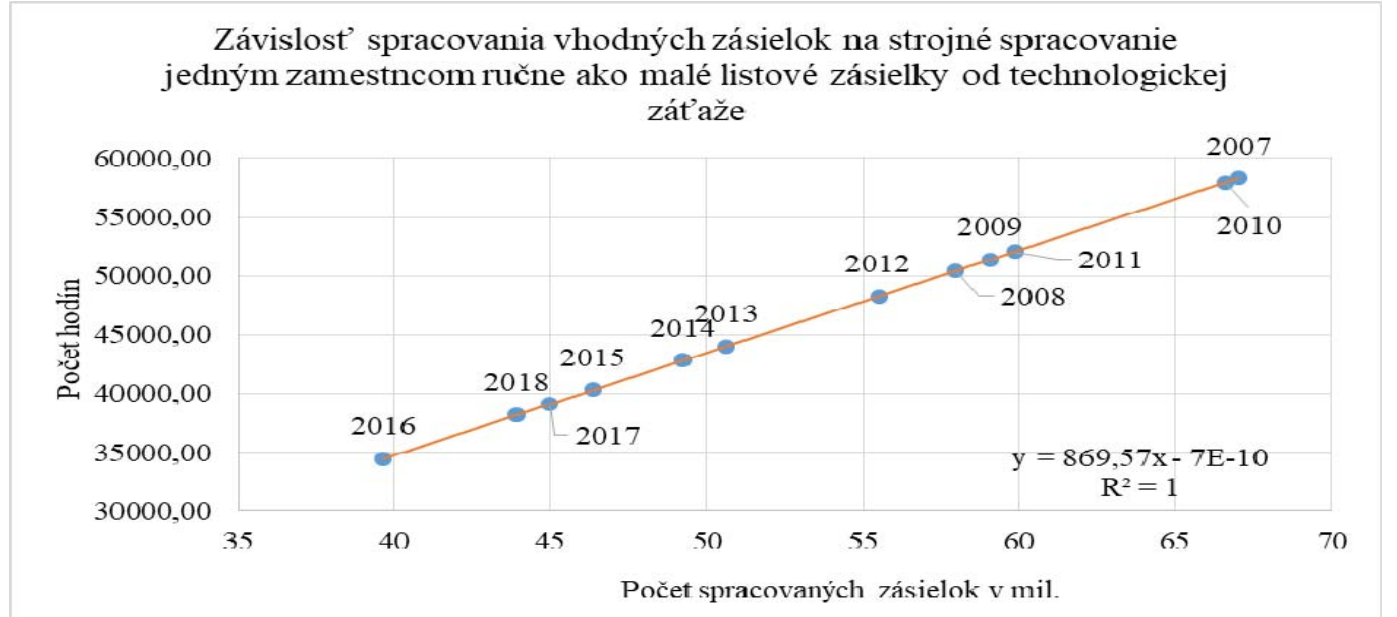

Obrázok 7 Závislost’ spracovania zásielok jedným zamestnancom manuálne ako malé listové zásielky od technologickej zát’aže 2007 - 2018 (Zdroj: autor)

Obrázok 7 znázorňuje lineárnym regresným modelom závislost' počtu hodín spracovaných listových zásielok vhodných na strojné spracovanie jedným zamestnancom ručne od počtu spracovaných vel'kých kusov je vysvetlených $100 \%$ variability v počte hodín. Táto závislost' je takmer dokonalá $\left(\mathrm{r}^{2}=1\right)$ a je štatisticky významná. Pri hodnote ručného spracovania boli brané do úhavy údaje o priemernej rýchlosti zamestnanca, ktorý triedi listové zásielky malých rozmerov. Pri poklese počtu listových zásielok vhodných na strojné spracovanie o 1 milión je sprevádzaný poklesom počtu hodín v priemere približne o 869,57. 


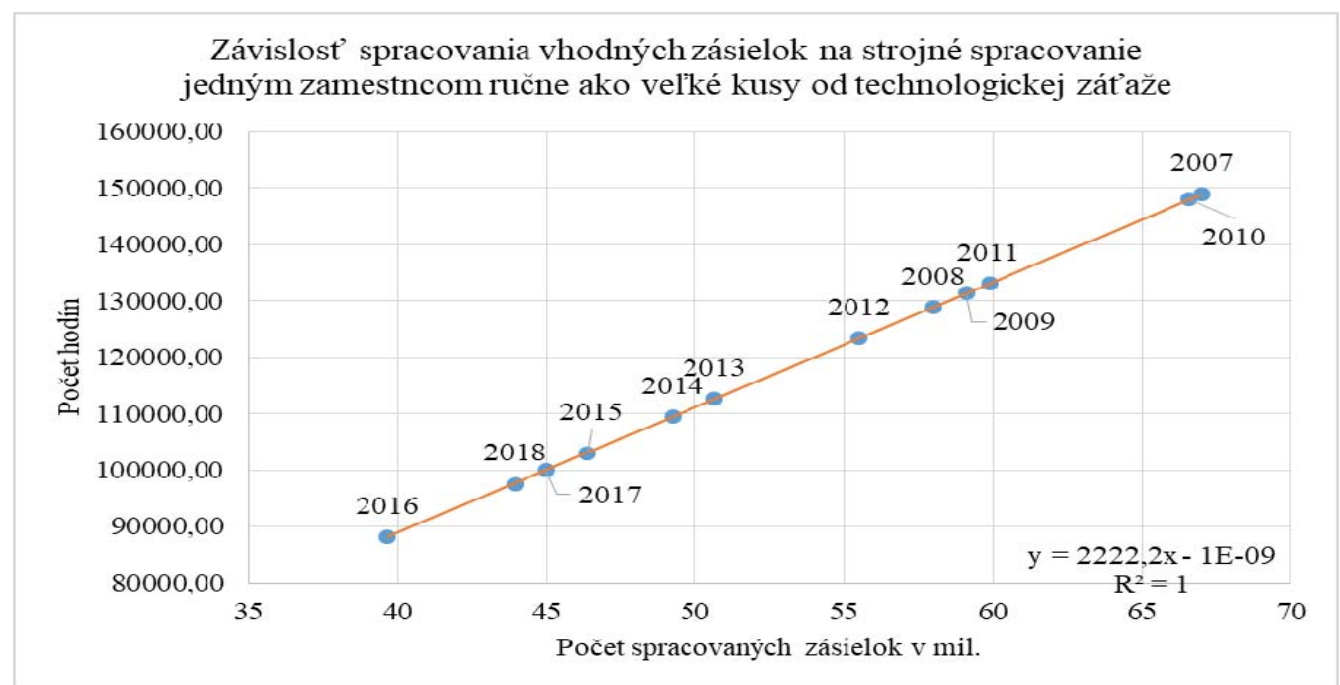

Obrázok 8 Závislost’ spracovania vhodných zásielok na strojné spracovanie jedným zamestnancom ručne ako vel'ké kusy od technologickej zát’aže 2007 - 2018 (Zdroj: autor)

Obrázok 8 znázorňuje lineárnym regresným modelom závislost' počtu hodín spracovaných listových zásielok vhodných na automatizované spracovanie jedným zamestnancom ručne od počtu spracovaných vel'kých kusov je vysvetlených $100 \%$ variability v počte hodín. Táto závislost' je takmer dokonalá $\left(\mathrm{r}^{2}=1\right)$ a je štatisticky významná. Pri poklese počtu listových zásielok vhodných na strojné spracovanie o 1 milión je sprevádzaný poklesom počtu hodín v priemere približne o 2222,2. Pri hodnote ručného spracovania boli brané do úhavy údaje o priemernej rýchlosti jedného zamestnanca, ktorý triedi listové zásielky malých rozmerov.

3. Obdobným spôsobom boli skúmané závislosti aj pre spracovávanie listových zásielok označených ako vel'ké kusy ktoré v súčasnej dobe spracovatel'ské strediská triedia manuálne. Pre uvedený prípad platí nasledovné:

- lineárnym regresným modelom závislost' prepočítaného počtu hodín na jedného zamestnanca od počtu listových zásielok resp. vel'kých kusov je vysvetlených 60,84 \% variability $\mathrm{v}$ počte zamestnancov. Táto závislost' je takmer dokonalá $\left(\mathrm{r}^{2}=1\right)$ a je štatisticky významná. Nárast počtu zásielok o 1 milión je sprevádzaný poklesom počtu zamestnancov v priemere približne o 2222,2. Vel'ké kusy predstavujú pre jedného zamestnanca najväčšie časové zat’aženie.

Ak by sme do úvahy brali časovú náročnost' práce zamestnanca pri triedení zásielok „vel'ké kusy prostredníctvom automatizovanej riediacej linky“ závislost' by bola modelová nasledovne:

- lineárnym regresným modelom závislost' počtu hodín spracovania vel'kých kusov jedným zamestnancom od počtu spracovaných vel'kých kusov je vysvetlených $100 \%$ variability $\mathrm{v}$ počte hodín. Táto závislost' je takmer dokonalá $\left(\mathrm{r}^{2}=1\right)$ a je štatisticky významná. Pri poklese počtu vel'kých kusov o 1 milión je sprevádzaný poklesom počtu hodín v priemere približne o 130,91. Rozdiel medzi časovou náročnost'ou zobrazenej v obrázku 40. je 2091,29 hodín. V prípade ak jeden zamestnanec bude triedit' vel'ké kusy na automatizovanej triediacej linke, tak pri zvýšení počtu listových zásielok o 1 milión by pracoval o 2091,29 hodín kratšie oproti klasickému ručnému triedeniu.

Ak by sme modelovali situácia, že tieto zásielky budeme triedit' automatizovane len v objeme $50 \%$ a ostatný objem ručne závislost' by bola následovná: 
- lineárnym regresným modelom závislost' počtu hodín spracovania vel'kých kusov jedným zamestnancom $\mathrm{z}$ toho $50 \%$ manuálne a 50\% automatizovane od počtu spracovaných vel'kých kusov je vysvetlených $100 \%$ variability v počte hodín. Táto závislost' je takmer dokonalá $\left(\mathrm{r}^{2}=1\right)$ a je štatisticky významná. Pokles počtu vel'kých kusov o 1 milión je sprevádzaný poklesom počtu hodín v priemere približne o 500,24. Rozdiel v počte hodín pri spracovávaní všetkých „vel'kých kusov“ automatizovanou linkou je vyšší o 369,33 .

\section{Záver}

Dopady Industry 4.0 neobídu žiadnu z krajín. Kl’účovou otázkou ostane, či sa Industry 4.0 stane príležitost’ou a výzvou, alebo hrozbou s nežiadúcim dopadom na konkurencieschopnost' hospodárstva.

Zo skúmaných závislosti vybraných parametrov v podmienkach poskytovatel'a univerzálnej služby možno interpretovat', že digitalizácia má vplyv na počet zásielok. Počet pripojení na internet je odrazený zvýšeným počtom balíkov a zníženým počtom listových zásielok. Pri každom poklese pripojení na internet sa zníži počet listových zásielok, čo má dopad aj na zníženie celkového počtu zamestnancov. Vzhl'adom na zvyšujúce sa objemy balíkových zásielok a mierne klesajúci počet listových zásielok sa zdá byt' pravdepodobné, že poštoví doručovatelia sú neohrozenou skupinou zamestnancov. Digitalizácia tento segment zamestnancov poskytovatel'a univerzálnej služby neohrozuje, nakol'ko pri riešení poslednej míle operátor neuvažuje s nasadením autonómnych prostriedkov obsluhy dodacích miest.

V segmente zamestnancov pracujúcich v triediarňach poštových zásielok je zjavné, že automatizácia výrazne pomáha znížit' časovú náročnost' práce. V súčasnej dobe je vel'ké množstvo zásielok spracovávaných manuálne a to aj napriek tomu, že povaha a vlastnosti niektorých druhov listových zásielok by umožnili použitie už zavedenej automatizácie (bez nutnosti d'alších investícií) za predpokladu, že poštový operátor zmení nastavené technologické postupy, ktorými sú zamestnanci viazaní. V budúcnosti sa predpokladá nutnost' implementácie hybridných triediacich zariadení, ktoré umožnia triedenie rôznych druhov zásielok.

\section{Literatúra}

[1] ARNTZ, M., GREGORY, T., ZIERAHN, U.: The Risk of Automation for Jobs in OECD Countries. OECD Social, Employment And Migration Working Papers No. 189, OECD 2016

[2] FREY, B.C., OSBORNE, A.,M.: The Future of Employment: How Susceptible are Jobs to Computerisation?, University of Oxford, Oxford, 2013

[3] CHINORACKÝ,R., ČOREJOVÁ, T.: Impact of digital technologies on labor market and the transport sector. In: TRANSCOM 2019: conference proceedings. - ISSN 2352-1465. 1. vyd. - Amsterdam: Elsevier Science, 2019. - s. 994-1001

[4] CHINORACKÝ, R., TURSKÁ, S., MADLEŇÁKOVÁ, L.: Does Industry 4.0 have the same impact on employment in the sectors? In: Management. - ISSN 1854-4223. - Roč. 14, č. 1 (2019), s. 5-17 - Spôsob prístupu: http://www.hippocampus.si/ISSN/18544231/14_1.pdf

[5] MANYIKA, J., CHUI, M., MIREMADI, M., BUGHIN, J., GEORGE, K., WILLMOTT, P., DEWHURST, M.: A Future that Works: Automation, Employment, and Productivity. McKinsey \& Company 2017

[6] MELOUN,M., MILITKÝ,J: Statistická analýza experimentálních dat. Praha/Czech Republic: Academia. 953 p., 2004. 
[7] PEARSON, K.: Mathematical contributions to the theory of evolution, "On the Theory of Contingency and Its Relation to Association and Normal Correlation", London, Dulau and Co, p. 46

[8] STRENITZEROVÁ, M., ŠTALMACHOVÁ, K.: Sustainable human resources management in the postal sector - employee engagement. In: Pošta, Telekomunikácie a Elektronický obchod: elektronický časopis Katedry spojov. - ISSN 1336-8281 - Roč. 15, č. 1 (2020), s. 82-90 - Spôsob prístupu: https://fpedas.uniza.sk/ ks/casopis/pdf/I2020/I2020.pdf

[9] TURSKÁ, S., CHINORACKÝ, R., KUROTOVÁ, J. JACULJAKOVÁ, S. RYBICKA, I.: Delivery models in last mile logistics. In: Transport and Communications. - ISSN 13395130. - Roč. 6, č. 2 (2018), s. 20-24

[10]Európsky prehl'ad výsledkov inovácie 2018. Dostupné na internete: http://europa.eu/rapid/press-release_IP-18-4223_sk.htm

[11] Industry 4.0 and its Implications for EU industrial Policy. Dostupné na internete: http://www.prog.sav.sk/sites/default/files/201803/Priemysel.4.0.a.jeho_.implikacie.pre_.priemyselnu.politiku.pdf

[12]Industry 4.0 - výrazný trend V novodobej logistike. Dostupné na internete: https://www.info.sk/sprava/107916/industry-40-vyrazny-trend-v-novodobej-logistike/

[13]NÁSTUP INDUSTRY 4.0. Dostupné na internete: http://files.sam-km.sk/2000003756837469375/Zalezakova_Nastup_industry_4.0.pdf

[14] Slovensko je $\mathrm{v}$ inováciách na chvoste. Dostupné na internete: https://innonews.blog/2020/11/23/slovensko-je-v-ekologickych-inovaciach-na-chvoste$\mathrm{eu} /$

[15] The Regional Innovation Scoreboard report 2017. Dostupné na internete: https://ec.europa.eu/docsroom/documents/31491

[16]TRENDUSTRY 2018: Nemusíte byt' vel'kými rybami, budúcnost' patrí rybám rýchlym. Dostupné na internete: https://sova.sk/trendustry-2018-nemusite-byt-velkymi-rybamibuducnost-patri-rybam-rychlym/

[17]Úroveň robotiky na Slovensku má stúpajúci charakter. Dostupné na internete: https://industry4um.sk/uroven-robotiky-na-slovensku-ma-stupajuci-charakter-nesmiemevsak-zaspat/

[18]https://eraportal.sk/aktuality/najinovativnejsie-ekonomiky-sveta-2020

[19]https://vedanadosah.cvtisr.sk/zamestnanost-v-sektore-ikt-v-ramci-europy

[20] https://statistikapspp.sk/korelacia/>

[21] https://www.trans.eu/sk/blog/logistika-4-0/efektivna-logistika-poslednej-mile/)

[22] https://europskenoviny.sk/2017/07/22/eurostat-v-it-sektore-pracovalo-v-eu-minuly-rokviac-ako-8-milionov-odbornikov/

[23] https://ec.europa.eu/regional_policy/sk/newsroom/news/2019/06/17-06-2019-2019innovation-scoreboards-the-innovation-performance-of-the-eu-and-its-regions-isincreasing

[24] https://opac.crzp.sk/?fn=detailBiblioForm\&sid=BB60B769A491B65140F73DF2173F\&s $\mathrm{eo}=\mathrm{CRZP}$-detail-kniha

\section{Grantová podpora}

VEGA 1/0152/18 Obchodné a podnikatel'ské modely a platformy v digitálnom prostredí 